\title{
Standard drug consumption: a study with elderly people in Primary Health Care
}

\author{
Padrão de consumo medicamentoso: um estudo com idosos na Atenção Primária à Saúde \\ Consumo estándar de drogas: un estudio con personas mayores en Atención Primaria de Salud
}

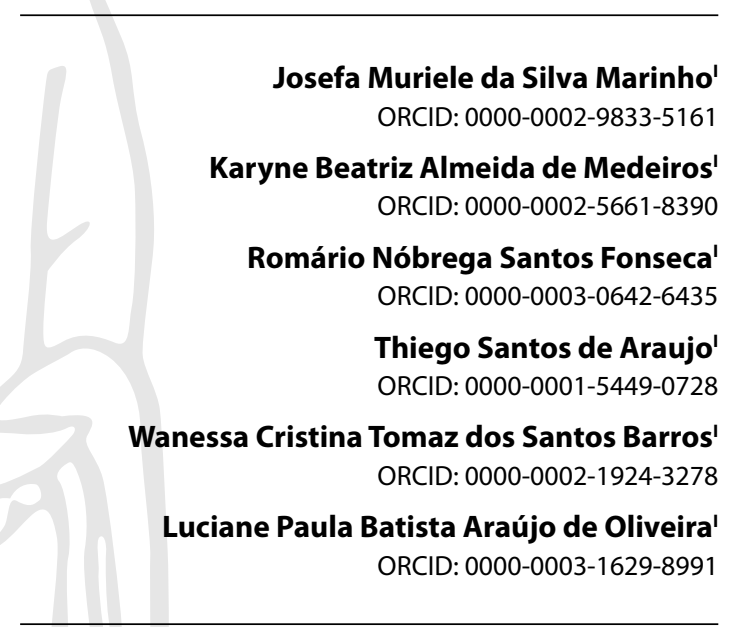

'Universidade Federal do Rio Grande do Norte. Santa Cruz, Rio Grande do Norte, Brazil.

How to cite this article: Marinho JMS, Medeiros KBA, Fonseca RNS, Araújo TS, Barros WCTS, Oliveira LPBA. Standard drug consumption: a study with elderly people in Primary Health Care. Rev Bras Enferm. 2021;74(3):e20200729. https://doi.org/10.1590/0034-7167-2020-0729

Corresponding author: Luciane Paula Batista Araújo de Oliveira E-mail: lucianepoliveira@yahoo.com.br

EDITOR IN CHIEF: Dulce Barbosa ASSOCIATE EDITOR: Hugo Fernandes

Submission: 07-01-2020

Approval: $12-06-2020$

\begin{abstract}
Objective: To identify the pattern of medication consumption among the elderly assisted in Primary Health Care. Methods: Descriptive, quantitative, cross-sectional study, with a sample of 315 elderly people, in a city in rural Rio Grande do Norte. Results: The average age was 72.41 years, with an average consumption of 3.15 medications per day, ranging from 1 to 16 medications daily. There was a prevalence of antihypertensives, antidiabetics, hypolipidemic and psychotropic drugs. 238 different drugs were mentioned, 15 of which were "potentially inappropriate drugs" for the elderly. Most of these patients follow treatment according to medical prescription, with low self-medication. Most elderly people buy their drugs, although many are available for free. Conclusion: The most consumed drugs are consistent with the most reported diseases (hypertension and diabetes). The daily use of inappropriate medications for the elderly is worrying, especially psychotropics, given the risks of dependence or health complications of these users.

Descriptors: Aged; Drug Utilization; Primary Health Care; Nursing; Pharmacoepidemiology.
\end{abstract}

\section{RESUMO}

Objetivo: Identificar o padrão de consumo medicamentoso de idosos atendidos na Atenção Primária à Saúde. Método: Estudo descritivo, quantitativo, transversal, cuja amostra foi de 315 idosos residentes num município do interior do Rio Grande do Norte. Resultados: A média de idade foi de 72,41 anos, com consumo médio de 3,15 medicamentos por dia, variando de 1 a 16 medicamentos diários. Houve prevalência de anti-hipertensivos, antidiabéticos, hipolipemiantes e psicotrópicos. Foram mencionados 238 medicamentos diferentes, dos quais 15 eram "medicamentos potencialmente inapropriados" para idosos. A maioria desses pacientes segue tratamento conforme prescrição médica, com baixa automedicação. A maior parte dos idosos compra seus medicamentos, embora muitos estejam disponíveis gratuitamente. Conclusão: Os medicamentos mais consumidos são coerentes com as doenças mais relatadas (hipertensão e diabetes). É preocupante o uso diário de medicamentos inapropriados para idosos, com destaque para os psicotrópicos, dados os riscos de dependência ou de complicações da saúde desses usuários.

Descritores: Idoso; Uso de Medicamentos; Atenção Primária à Saúde; Enfermagem; Farmacoepidemiologia.

\section{RESUMEN}

Objetivo: Identificar el estándar de consumo medicamentoso de ancianos atendidos en la Atención Primaria de Salud. Métodos: Estudio descriptivo, cuantitativo, transversal, cuya muestra fue de 315 ancianos residentes en municipio del interior de Rio Grande do Norte. Resultados: Mediana de edad fue de 72,41 años, con consumo mediano de 3,15 medicamentos al día, variando de 1 a 16 medicamentos diarios. Hubo prevalencia de antihipertensivos, antidiabéticos, hipolipemiantes y psicotrópicos. Mencionaron 238 medicamentos diferentes, de los cuales 15 eran "medicamentos potencialmente inapropiados" para ancianos. Mayoría de esos pacientes sigue tratamiento conforme prescripción médica, con baja automedicación. Mayor parte de los ancianos compra sus medicamentos, aunque muchos sean gratuitos. Conclusiones: Los medicamentos más consumidos son coherentes con las enfermedades más relatadas (hipertensión y diabetes). Es preocupante el uso diario de medicamentos inapropiados para ancianos, con destaque para los psicotrópicos, datos los riegos de dependencia o de complicaciones de la salud de esos usuarios. Descriptores: Anciano; Uso de Medicamentos; Atención Primaria de Salud; Enfermería Farmacoepidemiología. 


\section{INTRODUCTION}

The indiscriminate use of medicines is now a common practice among the population, which seems to be characteristic of contemporary life. In Brazil, the lack of clinical protocols and easy access to medicines can contribute to the practice of polypharmacy in the elderly population ${ }^{(1)}$.

Polypharmacy consists, in general, in the concomitant use of multiple medications, a common practice in the elderly because they have multi-morbidities. It is associated with a higher occurrence of falls, drug interactions, increased length of hospital stay and readmission to the hospital soon after discharge ${ }^{(2)}$.

In the absence of a consensus on the number of drugs that would constitute polypharmacy, other authors carried out a systematic review that found 138 definitions, some of which establish as a criterion only the number of drugs, and others also consider the time of treatment use. The numerical criteria ranged from 2 or more to 11 or more drugs per day as a definition of polypharmacy, and the value most frequently mentioned in the literature was the use of 5 or more drugs per day to represent $\mathrm{it}^{(2)}$.

In our professional practice, we observe daily that the elderly assisted in Primary Health Care (PHC) usually consume a high number of medications, prescribed or not, which can bring both benefits and losses to their health status. Among the duties of the PHC nurse in health care for the elderly, is to guide the elderly, family members and/or caregiver on the correct use of medicines. This important role can be developed both in home care and during the nursing consultation, which includes, among other precautions, the prescription of medications according to protocols or regulations established by the municipal manager and observance of the legal provisions of the profession ${ }^{(3)}$.

In view of the exposed problem, a literature search was carried out for studies dealing with nursing and medication use by the elderly in the city of Santa Cruz/RN or other municipalities in the region, in order to visualize the knowledge produced on the subject, so far, in this area. locality. Although there are already many researches involving the health of the elderly in this region, only one thesis ${ }^{(4)}$ and one $\operatorname{article}^{(5)}$ on the specific theme of this manuscript were identified, showing that there is still a knowledge gap in the area studied.

\section{OBJECTIVE}

Identify the pattern of medication consumption in the elderly treated in Primary Health Care.

\section{METHODS}

\section{Ethical aspects}

All ethical precepts of the Resolution of the National Health Council (CNS) No. 466/12, which deals with research with human beings, were obeyed, and the research project was appreciated and approved by the Research Ethics Committee of the Faculty of Health Sciences of the Trairi (CEP FACISA), from the Federal University of Rio Grande do Norte (UFRN).

\section{Study design, period and location}

Quantitative, descriptive study with a cross-sectional view. In the preparation of this manuscript, the Strengthening the Reporting of Observational Studies in Epidemiology (STROBE) was used as a checklist, as provided by the EQUATOR network for observational studies.

The research was carried out in units of the Family Health Strategy (FHS) located in the urban area of the municipality of Santa Cruz, RN, Brazil. Data collection took place from August 2017 to August 2018.

\section{Population or sample; inclusion and exclusion criteria}

The participants in this research were elderly people living in the city of Santa Cruz / RN. The total elderly population of the municipality is 4,177 elderly people, of whom 3,611 live in the urban area; and 566, are in the countryside ${ }^{(6)}$. The sample was calculated using the EPIINFO 6.0 software, based on this total number of elderly people, considering a $95 \%$ confidence interval and $83 \%$ prevalence of medication use, identified in a similar study conducted by other authors ${ }^{(7)}$. Thus, a sample of 315 elderly people in the urban area and 50 in the rural area was calculated, and the present manuscript will address only the results found in the urban area.

The inclusion criteria were: being 60 years of age or older; registered with the FHS of that location. Those who did not have cognitive conditions to respond to the collection instrument were excluded from the study. Cognitive ability was verified by applying the Verbal Fluency Test (VFT), which consists of evoking the largest number of words in a semantic category - in this case, the category of animal names was used for 1 minute, whose score corresponds to the number of words mentioned by the elderly ${ }^{(8)}$.

\section{Study protocol}

For data collection, we used the structured interview technique by applying a form with closed questions, constructed and validated by the study HWBA - Health, Well-Being and Aging ${ }^{(9)}$, which received a small adaptation including questions for characterization sociodemographic of the participant. The block of specific questions on the theme has six questions about the drugs currently consumed, questioning, for example, the time of use, the person responsible for the prescription and forms of acquisition. The interviews were conducted individually and took place at the health unit or at the elderly's own residence, according to the best convenience for the participant.

\section{Analysis of results and statistics}

The database was built on Excel spreadsheets, version 2017, according to the following variables: Age group, Educational level, Monthly family income, Number of medicines used daily, Smoking, Alcoholism, Sedentary lifestyle, Physical activity, Pathological personal history (considering pre-existing and current diseases), as part of the characterization of the participants. As for the specific object of the study, the variables were: Therapeutic class, 
Prescriber, Presentation of medicines, Fractionation, Compliance with the prescription, Form of purchase of the medicine.

In the treatment of the data, the drugs used were listed by their generic names and classified according to the classification of the World Health Organization's Anatomical Therapeutic Chemical Classification (ATC) ${ }^{(10)}$. Thus, in the results of this study, the consumption pattern will be presented according to the therapeutic classes.

The Statistical Package for the Social Sciences (SPSS) software, version 25.0, was used. In the quantitative variables evaluated, descriptive statistics of trend and data dispersion measures were analyzed: minimum, maximum, average and standard deviation; in qualitative variables, descriptive analysis was carried out by means of distributions of absolute and relative frequencies (\%). The results will be presented below by means of tables and a figure; for a better visualization of the implications of the use of potentially inappropriate medications (PIM) for the elderly, a descriptive table was created to be presented in the discussion of the results.

\section{RESULTS}

The average age of the participants was 72.41 years, and the sample was predominantly female (65.5\%). The elderly took an average of 3.15 medications per day, and this number varied from 1 to 16 medications daily. These and other characteristics will be presented in Table 1 below.

Still on Table 1, it is justified that the age of 75 years was adopted as a cut-out for the age group due to the fact that, up to that age, the elderly can be considered as youngest old ${ }^{(11)}$, that is, young elderly, one group that tends to have better health condition when compared to the older ones ${ }^{(11)}$. The classification of people as elderly or not has been the subject of recent debates, and countries like Italy have already adopted 75 years as an age criterion to demarcate this stage of life due to the increase in life expectancy and better health conditions of the population ${ }^{(12)}$.

The 315 participants mentioned 238 different drugs, from the most diverse therapeutic classes. Among these, 15 are classified as potentially inappropriate drugs (PIM) for the elderly ${ }^{(13-14)}$ and were used with the following frequency: doxazosin (1.58\%); amitriptyline, insulin, ibuprofen (1.26\% each); alprazolam, lorazepam, digoxin, naproxen, cyclobenzaprine, diltiazem ( $0.95 \%$ each); nortriptyline, paroxetine, piroxicam ( $0.63 \%$ each); phenobarbital and tramadol ( $0.31 \%$ each). PIMs were used with the following daily frequency: 122 elderly people used one PIM per day, 32 elderly people used two per day, and 2 elderly people even used three PIM per day.

When organized by therapeutic class, the most consumed drugs were antihypertensive, anti-diabetic, lipid-lowering and psychotropic drugs, as shown in Table 2.

The "others" category includes more than 20 different classes of drugs that, individually, were mentioned by few participants as anticoagulants, corticosteroids, antihistamines, antineoplastics, antimicrobials, antiparkinsonians and anticholinergics.

General characteristics related to the consumption of medications from the three most frequent classes (antihypertensive, antidiabetic and hypolipidemic) were also investigated, considering: responsible for the prescription; presentation of medicines; use of a fractional dose or not; use according to prescription (Table 3).
Table 1 - Characterization of study participants, Santa Cruz, Rio Grande do Norte, Brazil, 2018

\begin{tabular}{|c|c|c|}
\hline Characteristics & Frequencies & $\%$ \\
\hline \multicolumn{3}{|l|}{ Sex } \\
\hline Female & 205 & 65.08 \\
\hline Male & 110 & 34.92 \\
\hline \multicolumn{3}{|l|}{ Age group } \\
\hline Up to 75 years & 222 & 70.48 \\
\hline Over 75 years & 93 & 29.52 \\
\hline \multicolumn{3}{|l|}{ Educational level* } \\
\hline Illiterate / Semi-literate & 165 & 53.40 \\
\hline Complete early childhood education & 36 & 11.65 \\
\hline Incomplete early childhood education & 50 & 16.19 \\
\hline Complete elementary school & 17 & 5.50 \\
\hline Incomplete elementary school & 17 & 5.50 \\
\hline Complete high school & 10 & 3.24 \\
\hline Incomplete high school & 9 & 2.91 \\
\hline Complete higher education & 4 & 1.29 \\
\hline Incomplete higher education & 1 & 0.32 \\
\hline \multicolumn{3}{|l|}{ Monthly family income } \\
\hline Up to 1 minimum wage & 188 & 62.05 \\
\hline Above 1 minimum wage & 115 & 37.95 \\
\hline \multicolumn{3}{|l|}{ Number of medications per day } \\
\hline Up to 3 & 207 & 65.71 \\
\hline 4 or more & 108 & 34.29 \\
\hline \multicolumn{3}{|l|}{ Smoking } \\
\hline Yes & 30 & 9.71 \\
\hline No & 279 & 90.29 \\
\hline \multicolumn{3}{|l|}{ Ethics } \\
\hline Yes & 17 & 5.50 \\
\hline No & 292 & 94.50 \\
\hline \multicolumn{3}{|l|}{ Physical activity } \\
\hline Yes & 117 & 37.86 \\
\hline No & 192 & 62.14 \\
\hline \multicolumn{3}{|l|}{ Personal background (multiple answer) } \\
\hline Arterial hypertension & 213 & 67.62 \\
\hline Diabetes & 189 & 60.00 \\
\hline Osteoarticular diseases & 88 & 27.94 \\
\hline Others & 74 & 23.49 \\
\hline Total & 315 & 100.00 \\
\hline
\end{tabular}

Note: *Regarding education, it was considered: child education (training up to 5 years old); fundamental, lasting nine years of study; high school, three years in duration; and higher, having studied at the undergraduate level. The illiterate/semi-illiterate category includes those with no year of study or who only know how to sign their names.

Table 2 - Frequency of medication consumption according to the most used therapeutic classes (multiple response) N=315, Santa Cruz, Rio Grande do Norte, Brazil, 2018

\begin{tabular}{lcc}
\hline Therapeutic classes & $\mathbf{n}$ & $\%$ \\
\hline Antihypertensive & 241 & 76.50 \\
Antidiabetic & 74 & 23.49 \\
Hypolipidemic & 71 & 22.53 \\
Psychotropic & 65 & 20.63 \\
Anti-inflammatories & 50 & 15.87 \\
Antiulcer & 24 & 7.62 \\
Supplements & 24 & 7.62 \\
Corticosteroids & 22 & 6.98 \\
Bisphosphonates & 21 & 6.67 \\
Pain relievers & 18 & 5.71 \\
Thyroid hormones & 16 & 5.08 \\
Muscle relaxant & 16 & 5.08 \\
Vitamins & 14 & 4.44 \\
Diuretics & 10 & 3.17 \\
Others & 112 & 35.55 \\
\hline
\end{tabular}

Regarding the use of medicines by the elderly, a relevant feature is the time of use, considering that the classes most cited are those aimed at the treatment of chronic diseases. The 
average time of use was 6.61 years for antidiabetics, 6.10 years for hypolipidemic patients and 4.37 years for antihypertensives.

Table 3 - General characteristics of the main therapeutic classes used, $\mathrm{N}=$ 315, Santa Cruz, Rio Grande do Norte, Brazil, 2018

\begin{tabular}{|c|c|c|c|}
\hline & Response & $\begin{array}{l}\text { Absolute } \\
\text { frequency }\end{array}$ & $\%$ \\
\hline \multicolumn{4}{|l|}{ Anti-hypertensive } \\
\hline Prescriber & $\begin{array}{l}\text { Physician } \\
\text { Own account }\end{array}$ & $\begin{array}{c}350 \\
2\end{array}$ & $\begin{array}{c}99.43 \\
0.57\end{array}$ \\
\hline Presentation of medicines & $\begin{array}{l}\text { Pills } \\
\text { Capsules } \\
\text { Drops }\end{array}$ & $\begin{array}{c}342 \\
8 \\
3\end{array}$ & $\begin{array}{c}96.88 \\
2.27 \\
0.85\end{array}$ \\
\hline Fractionation & $\begin{array}{l}\text { Yes } \\
\text { No }\end{array}$ & $\begin{array}{c}21 \\
323\end{array}$ & $\begin{array}{c}6.10 \\
93.90\end{array}$ \\
\hline Compliance with the prescription & $\begin{array}{l}\text { Yes } \\
\text { No }\end{array}$ & $\begin{array}{c}321 \\
20\end{array}$ & $\begin{array}{c}93.31 \\
5.81\end{array}$ \\
\hline \multicolumn{4}{|l|}{ Antidiabetic } \\
\hline Prescriber & Physician & 85 & 100.00 \\
\hline Presentation of medicines & $\begin{array}{l}\text { Pills } \\
\text { Injectable liquid } \\
\text { Drops }\end{array}$ & $\begin{array}{c}80 \\
4 \\
1\end{array}$ & $\begin{array}{c}94.12 \\
4.71 \\
1.18\end{array}$ \\
\hline Fractionation & $\begin{array}{l}\text { Yes } \\
\text { No }\end{array}$ & $\begin{array}{c}7 \\
78\end{array}$ & $\begin{array}{c}8.24 \\
91.76\end{array}$ \\
\hline Compliance with the prescription & $\begin{array}{l}\text { Yes } \\
\text { No }\end{array}$ & $\begin{array}{c}7 \\
78\end{array}$ & $\begin{array}{c}8.24 \\
91.76\end{array}$ \\
\hline \multicolumn{4}{|l|}{ Hypolipidemic } \\
\hline Prescriber & Physician & 54 & 100.00 \\
\hline Presentation of medicines & $\begin{array}{l}\text { Pills } \\
\text { Capsules } \\
\text { Drops }\end{array}$ & $\begin{array}{c}52 \\
1 \\
1\end{array}$ & $\begin{array}{c}96.30 \\
1.85 \\
1.85\end{array}$ \\
\hline Fractionation & $\begin{array}{l}\text { Yes } \\
\text { No }\end{array}$ & $\begin{array}{c}3 \\
49\end{array}$ & $\begin{array}{c}5.77 \\
94.23\end{array}$ \\
\hline Compliance with the prescription & $\begin{array}{l}\text { Yes } \\
\text { No }\end{array}$ & $\begin{array}{c}50 \\
2\end{array}$ & $\begin{array}{c}96.15 \\
3.85\end{array}$ \\
\hline
\end{tabular}
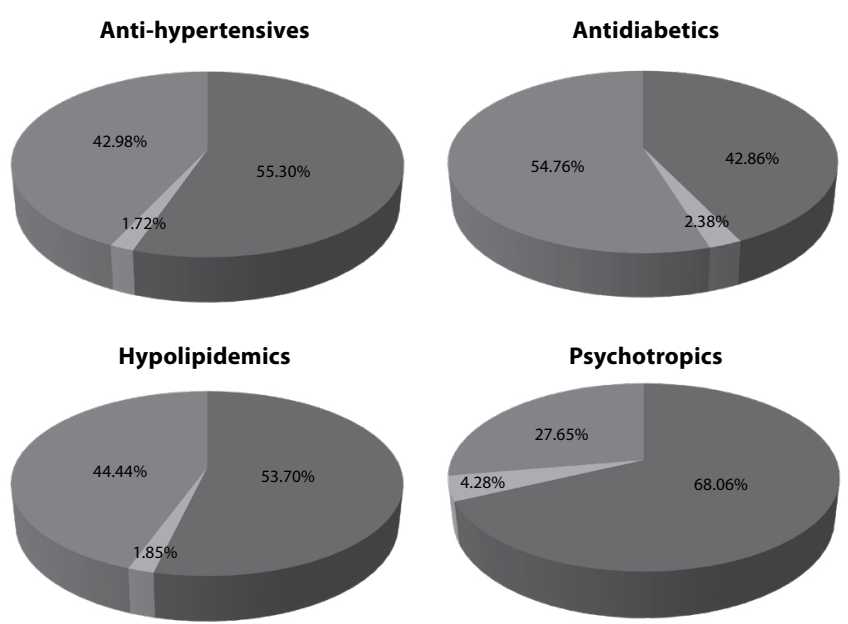

Private community pharmacies
Public servant assistance programs
Unified Health System

Figure 1 - Ways of purchasing drugs, according to therapeutic classes most consumed by the elderly, N = 315, Santa Cruz, Rio Grande do Norte, Brazil, 2018
Regarding the form of acquisition, it was identified that, in the therapeutic classes presented, most of the elderly bought their drugs with their own resources or from family members in private community pharmacies, although many of these were available free of charge in establishments of the Unified Health System (SUS). These and other forms of drug purchase are shown in Figure 1.

\section{DISCUSSION}

Most of the participants in this study were female, showing that the municipality of Santa Cruz/RN follows the trend of the feminization of old age phenomenon, also pointing to a greater demand for services by elderly women ${ }^{(15)}$. Therefore, it is important that professionals are trained in specific topics of this public and that health services are prepared to meet the desires of the aging woman ${ }^{(16)}$, especially in the PHC services, as they are configured as the preferred gateway to SUS.

More than half of the participants declared themselves to be illiterate and two thirds of the total interviewees earned up to a minimum wage, reinforcing that the elderly make up the portion of Brazilians with the lowest income. In addition to having low income, the elderly are the Brazilians most susceptible to the socalled financial violence, a phenomenon that has been growing in recent years in Brazil $^{(17)}$.

The interviewed elderly people report having healthy lifestyle habits, since most of them deny smoking and drinking and claim to practice physical activity; the most frequent diseases were hypertension and diabetes, corroborating data from a study carried out with elderly men in another municipality in the same state ${ }^{(18)}$, which portrays the reality of the elderly assisted by the FHS.

An important finding in this study was polypharmacy, since one third of the elderly used four or more medications per day, a practice that seems to be associated with the fact that they live with multiple chronic diseases, as found in other studies ${ }^{(19-21)}$. Polypharmacy results in lower adherence to pharmacological treatment, as already demonstrated by other authors who researched adherence to treatment with antihypertensive drugs. They identified that adherence begins to decrease after 70 years of age and when daily consumption exceeds four medications. The use of nine or more medications per day is associated with lower adherence, regardless of age ${ }^{(21)}$. It is important that professionals who care for the elderly in the scope of the FHS are aware of the high consumption of medicines by this population, being able to use the services in programs such as Hiperdia, in the case of nurses and doctors, as opportunities to promote the safe and rational use of medicines.

The consumption of 15 drugs considered inappropriate for the elderly was identified, an analysis that considered the current version of the Beers Criteria, an international recommendation that lists drugs to be avoided in this population because of the possibility of causing more harm than benefit, compared to alternative treatments ${ }^{(22)}$. In Brazil, there is already a consensus published in 2016 and based on international criteria whose applicability can be facilitated by being translated into Portuguese ${ }^{(13)}$.

It is essential that PHC health professionals are aware of these criteria in order to make safer prescriptions for elderly patients. In order to promote the dissemination of this information, the main 
implications of the use of PIM for the elderly according to the drugs used by the participants of the present study are listed below.

It is noteworthy that, among the PIMs mentioned, many were psychotropic, gathering antidepressants, benzodiazepines and anticonvulsants. In the sample studied, $20.63 \%$ of the elderly used at least one medication of this class, something of concern because of the risks of dependence, adverse and increased side effects in the elderly population ${ }^{(23)}$.

The use of psychotropic drugs in the elderly is associated with females, worse health perception, common mental disorder and complaints of emotional problems. For this reason, the importance of an accurate risk-benefit assessment and the rational use of this group of drugs is highlighted, since on the one hand it can help to rescue the functional potential of individuals, on the other hand it can increase the likelihood of intoxications and dependence physical and psychic ${ }^{(23)}$. In this sense, the importance of actions to promote the mental health of the elderly is seen as a shared responsibility among users, family members, community and professionals in this context of health care.

A study carried out in the interior of Bahia, with a sample and reality similar to this article, found that $20.3 \%$ of the elderly in polypharmacy used potentially inappropriate medications, and many $(44.2 \%)$ self-medicated ${ }^{(20)}$.
There is a tendency for the elderly to use self-medication more frequently than younger people, a dangerous practice, as it exposes them to the consumption of inappropriate medicines $^{(24)}$. Although the literature demonstrates these facts, in the present study, self-medication was a rare procedure among the participants, which may not accurately portray reality as there is a possibility that the participants will not assume the practice.

In addition to self-medication, it was investigated whether these elderly people used their medications as prescribed. In general, almost everyone says yes; however, when it came to antidiabetics, $91.76 \%$ did not take them as prescribed. This fact raises concerns in view that the elderly with diabetes needs unique management, especially those who are poly-medicated, due to the risk of suffering more drug interactions ${ }^{(25)}$.

Finally, an important result concerns the ways of acquiring medicines, since most of the interviewees bought them in private pharmacies, despite the fact that two thirds have a monthly family income of up to one minimum wage and many of these medicines are delivered free of charge at the Basic Health Units.

Other authors have identified that there are specific differences in relation to medication expenses by elderly people from different socioeconomic classes. While class A elderly people tend to purchase drugs in the private sector, class $C$ and $E$ use the

Chart 1 - Potentially inappropriate medications for the elderly and implications of use in elderly patients. Santa Cruz, Rio Grande do Norte, Brazil, 2019

\begin{tabular}{|c|c|}
\hline Medication (Class) & Implications of use in elderly patients \\
\hline $\begin{array}{l}\text { Doxazosin } \\
\text { (antihypertensive, alpha- } 1 \text { blocker) }\end{array}$ & $\begin{array}{l}\text { Use associated with high risk of orthostatic hypotension. Not recommended for routine } \\
\text { treatment of hypertension. There are alternatives with better risk-benefit ratio }{ }^{(14)} \text {. }\end{array}$ \\
\hline $\begin{array}{l}\text { Amitriptyline } \\
\text { (antidepressant) }\end{array}$ & Highly anticholinergic, sedative and causes orthostatic hypotension ${ }^{(14)}$. \\
\hline Insulin & Higher risk of hypoglycaemia. Avoid use based on capillary blood glucose ${ }^{(14)}$. \\
\hline $\begin{array}{l}\text { Alprazolam } \\
\text { Lorazepam } \\
\text { (benzodiazepines) }\end{array}$ & $\begin{array}{l}\text { They increase the risk of cognitive impairment, delirium, falls, fractures and car accidents. Avoid } \\
\text { all benzodiazepines to treat insomnia, restlessness or delirium. They may be appropriate to } \\
\text { treat seizures, REM sleep disorders, benzodiazepine and ethanol withdrawal syndrome, severe } \\
\text { generalized anxiety disorder, in perioperative anaesthesia and palliative care }{ }^{(14)} \text {. }\end{array}$ \\
\hline Digoxin & $\begin{array}{l}\text { The decrease in renal clearance with aging increases the risk of digitalis intoxication. In addition, } \\
\text { in heart failure, higher doses increase the risk of toxicity and do not offer greater benefits }{ }^{(14)} \text {. }\end{array}$ \\
\hline $\begin{array}{l}\text { Cyclobenzaprine } \\
\text { (muscle relaxant) }\end{array}$ & $\begin{array}{l}\text { Anticholinergic effects such as sedation and consequent risk of fracture. The effectiveness at } \\
\text { doses tolerated by the elderly is questionable }{ }^{(14)} \text {. }\end{array}$ \\
\hline $\begin{array}{l}\text { Diltiazem } \\
\text { (calcium channel blocker) }\end{array}$ & $\begin{array}{l}\text { They can worsen constipation. Have the potential to promote fluid retention and worsen heart } \\
\text { failure }^{(14)} \text {. }\end{array}$ \\
\hline $\begin{array}{l}\text { Nortriptyline } \\
\text { Paroxetine } \\
\text { (antidepressants) }\end{array}$ & $\begin{array}{l}\text { Both are highly anticholinergic, sedative and cause orthostatic hypotension }{ }^{(14)} \text {. Paroxetine can } \\
\text { produce ataxia, impaired psychomotor function, syncope and additional falls. May worsen } \\
\text { hyponatremia }{ }^{(13)} \text {. }\end{array}$ \\
\hline $\begin{array}{l}\text { lbuprofen } \\
\text { Naproxen } \\
\text { Piroxican } \\
\text { (non-steroidal anti-inflammatory drugs - NSAIDs) }\end{array}$ & $\begin{array}{l}\text { They increase the risk of gastrointestinal bleeding and peptic ulcer in those aged } 75 \text { years or } \\
\text { older or who use oral or parenteral corticosteroids, anticoagulants or antiplatelet agents. The } \\
\text { use of proton pump inhibitors reduces, but does not eliminate, the risk. Avoid chronic use, } \\
\text { except when there are no alternatives and it is possible to associate with a gastroprotective } \\
\text { agent. Piroxicam and ibuprofen have the potential to promote fluid retention and exacerbate } \\
\text { heart failure }{ }^{(14)} \text {. }\end{array}$ \\
\hline $\begin{array}{l}\text { Phenobarbital } \\
\text { (anticonvulsant, barbiturate) }\end{array}$ & $\begin{array}{l}\text { High proportion of physical dependence, tolerance to sleep induction and risk of overdose at } \\
\text { low doses }{ }^{(14)} \text {. Ability to produce ataxia, impaired psychomotor function, syncope and additional } \\
\text { falls }^{(13)} \text {. }\end{array}$ \\
\hline $\begin{array}{l}\text { Tramadol } \\
\text { (opioid) }\end{array}$ & $\begin{array}{l}\text { It can exacerbate or cause syndrome of inappropriate antidiuretic hormone (SIADH) or } \\
\text { hyponatremia syndrome; closely monitor sodium levels when starting or changing dosages in } \\
\text { adults }(14) \text {. Risk of: severe constipation; exacerbation of cognitive deficit; somnolence; postural } \\
\text { hypotension, vertigo. Decreases the seizure threshold, with acceptable use in patients with } \\
\text { well-controlled seizures, for which alternative agents have not been effective }{ }^{(13)} \text {. }\end{array}$ \\
\hline
\end{tabular}

Source: Research data compared to the Brazilian Consensus on Potentially Inappropriate Medicines for the elderly $y^{(13)}$ and the Beers Criteria - 2019 ${ }^{(14)}$ 
Brazilian public health system, but they still buy some in private establishments, even committing up to $10 \%$ of their monthly income to this goal(26). The cost generated by the purchase of medicines ends up reflecting the social inequalities experienced by elderly Brazilians ${ }^{(27)}$, because, in people with lower incomes, the expense of health treatment can compromise the family budget.

In view of the high consumption of medicines by the elderly and, at the same time, of the financial difficulties faced by a large part of this population, it is important to highlight the existence of the National List of Essential Medicines (RENAME), which lists the medicines made available to SUS users. RENAME must function as an instrument to guarantee access to pharmaceutical assistance ${ }^{(28)}$, and its existence must be known by health professionals so that it also serves as a means to promote the rational use of medicines.

\section{Study limitations}

The data in this study were collected through interviews with the elderly, without consulting their medical records to check whether the self-reported responses were compatible with the records in such documents, which may limit the results, for example, regarding the reliable number of elderly people who self-medicated.

The lack of information on the reason why the studied population buys drugs available in private institutions in the Unified Health System precludes information that could contribute to improving access and the work process in Primary Health Care.

\section{Contributions to the area of Nursing, Health or Public Policy}

The findings of this study nourish the body of knowledge of gerontological nursing, an emerging area in the country that has made efforts to consolidate its practices based on a theoretical-conceptual framework that considers the different ways of living and aging ${ }^{(29)}$.

The actions of gerontological nursing happen at all levels of complexity ${ }^{(29)}$, and the present investigation collaborates with its practice in $\mathrm{PHC}$ by providing a description of the pattern of drug consumption by the elderly, gathering information that can help the planning of care for the benefit of the elderly. safe use of medicines by elderly users, whether they are accompanied in nursing consultations, whether they are attended at home or those who participate in collective activities, such as social groups in health units.

Thus, these findings also provide subsidies for planning in local health, strengthening health promotion actions and preventing injuries to the elderly in the municipality. Also, they can inspire similar actions in other locations that present a reality like the one studied. In addition, it is expected to contribute to the development of a body of knowledge that will support the nursing actions in Primary Health Care, recognized for its strong characteristics of completeness and resolvability and for being the locus of privileged performance of care and management practices of nurses.

\section{CONCLUSION}

The elderly living in the urban area of the city of Santa Cruz/RN have a high consumption of medicines, with a daily average of 3.15 medicines per person, with cases in which the elderly used to use 16 medicines per day, a practice considered as polypharmacy and that exposes that user to other health problems. One of the consequences of polypharmacy is the greater chance of using drugs considered inappropriate for the elderly, which was also a reality identified in this study.

The pattern of medication consumption by these elderly people shows a prevalence of antihypertensive, antidiabetic, hypolipidemic and psychotropic drugs, consistent with the diseases most reported by the participants. On the other hand, the high consumption of psychotropics raises concerns about the mental health of the elderly interviewed, and the possibility of indiscriminate use of these drugs raises the need for reflections on mental health care and the need for intersectoral and interprofessional articulation to collaborate in the improving the use of these drugs and improving people's quality of life.

It is relevant the fact that a large part of this population purchases their drugs in private pharmacies, even when available in SUS services, which can impact the budget of these elderly people, further increasing the social gap of those who age in Brazilian municipalities. Therefore, the need for further research on this finding is pointed out in order to contribute to the adoption of measures that make it possible to reduce costs to users and expand their access to drug therapy in the public health network.

It is expected that the findings of this study will stimulate actions aimed at the rational and safe use of medicines, especially for the elderly who seek care in Primary Health Care.

\section{FUNDING}

Article from a research project funded by the department of Research (PROPESQ) of the Federal University of Rio Grande do Norte (UFRN).

\section{REFERENCES}

1. Pereira KG, Peres MA, lop D, Boing AC, Boing AF, Aziz M, et al. Polypharmacy among the elderly: a population-based study. Rev Bras Epidemiol. 2017;20(2):335-44. https://doi.org/10.1590/1980-5497201700020013

2. Masnoon N, Shakib S, Kalisch-Ellett L, Caughey GE. What is polypharmacy? a systematic review of definitions. BMC Geriatrics. 2017;17:230. https://doi.org/10.1186/s12877-017-0621-2

3. Ministério da Saúde (BR). Envelhecimento e saúde da pessoa idosa [Internet]. Brasília: Ministério da Saúde; 2006 [cited 2020 Jun 30$].$ Available from: http://bvsms.saude.gov.br/bvs/publicacoes/envelhecimento_saude_pessoa_idosa_n19.pdf

4. Oliveira LPBA. A pessoa idosa controlando sua situação de saúde/doença com o uso de medicamentos. [Tese]. Universidade Federal de Santa Catarina. Florianópolis, SC, 2015. 225p. 
5. Oliveira LPBA, Santos SMA. Combining various forms of treatment to health: a study of elderly in primary care. Texto Contexto Enferm. 2016;25(3):e3670015. https://doi.org/10.1590/0104-07072016003670015

6. Instituto Brasileiro de Geografia e Estatística (IBGE). Pirâmide etária [Internet]. 2010[cited 2015 Jun 20]. Available from: https://cidades.ibge. gov.br/brasil/rn/santa-cruz/panorama

7. Silva CSO, Pereira MA, Yoshitome AY, Rodrigues Neto JF, Barbosa DA. Evaluation of medication use among elderly population. Esc Anna Nery. 2010;14(4):811-8. https://doi.org/10.1590/S1414-81452010000400022

8. Martins NIM, Caldas PR, Cabral ED, Lins CCSA, Coriolano MGWS. Cognitive assessment instruments used in elderly Brazilians in the last five years. Ciênc Saúde Coletiva. 2019;24(7):2513-30. https://doi.org/10.1590/1413-81232018247.20862017

9. Organização Pan-Americana de Saúde (OPAS). Saúde, Bem estar e Envelhecimento (SABE): Condições de vida e saúde dos idosos do município de São Paulo [Internet]. Faculdade de Saúde Pública, Universidade de São Paulo; 2006 [cited 2015 Oct 15]. Available from: http:// hygeia3.fsp.usp.br/sabe/

10. World Health Organization (WHO). Collaborating Centre for Drug Statistics Methodology. Guidelines for ATC classification and DDD assignment 2020. Oslo, Norway, 2019[cited 2019 Dec 25]. Available from: https://www.whocc.no/filearchive/publications/2020_guidelines_ web.pdf

11. Lee SB, Oh JH, Park JH, Choi SP, Wee JH. Differences in youngest-old, middle-old, and oldest-old patients who visit the emergency department. Clin Exp Emerg Med. 2018;5(4):249-55. https://doi.org/10.15441/ceem.17.261

12. Lima KC, Mendes TCO. What is the ideal age limit for a person to be considered an older adult today? Rev Bras Geriatr Gerontol. 2019; 22(5):e190298. 2020. https://doi.org/10.1590/1981-22562019022.190298

13. Oliveira MG, Amorim WW, Oliveira CRB, Coqueiro HL, Gusmão LC, Passos LC. Brazilian consensus of potentially inappropriate medication for elderly people. Geriatr Gerontol Aging. 2016;10(4):168-81. https://doi.org/10.5327/Z2447-211520161600054

14. American Geriatrics Society Beers Criteria ${ }^{\oplus}$ Update Expert Panel. American Geriatrics Society 2019 Updated AGS Beers Criteria ${ }^{\circledR}$ for Potentially Inappropriate Medication use in older adults. JAGS. 2019;67(4):674-94. https://doi.org/10.1111/jgs.15767

15. Cruz PKR, Vieira MA, Carneiro JA, Costa FM, Caldeira AP. Difficulties of access to health services among non-institutionalized older adults: prevalence and associated factors. Rev Bras Geriatr Gerontol. 2020;23(6):e190113. https://doi.org/10.1590/1981-22562020023.190113

16. Medeiros SG, Morais FRR. Organization of healthcare services for elderly women: users' perceptions. Interface. 2015;19(52):109-19. https:// doi.org/10.1590/1807-57622014.0264

17. Santos AMR, Nolêto RDS, Rodrigues RAP, Andrade EMLR, Bonfim EG, Rodrigues TS. Economic-financial and patrimonial elder abuse: a documentary study. Rev Esc Enferm USP. 2019;53: e03417. https://doi.org/10.1590/S1980-220X2017043803417

18. Cavalcanti MVA, Oliveira LPBA, Medeiros ACQ, Távora RCO. Life habits of hypertensive elderly men. Rev Gaúcha Enferm. 2019;40:e20180115. https://doi.org/10.1590/1983-1447.2019.20180115

19. Walckiers D, Van Der Heyden J, Tafforeau J. Factors associated with excessive polypharmacy in older people. Arch Public Health. 2015;73:50. https://doi.org/10.1186/s13690-015-0095-7

20. Sales AS, Sales MGS, Casotti CA. Pharmacotherapeutic profile and factors associated with polypharmacy among the elderly in Aiquara, Bahia, Brazil, 2014. Epidemiol Serv Saude. 2017;26(1):121-32. https://doi.org/10.5123/S1679-49742017000100013

21. Kim SJ, Kwon OD, Han EB, Lee CM, Oh SW, Joh HK, et al. Impact of number of medications and age on adherence to antihypertensive medications: a nationwide population-based study. Medicine. 2019;98:49(e17825). https://doi.org/10.1097/MD.0000000000017825

22. Steinman MA, Fick DM. Using wisely: a reminder on the proper use of the American Geriatrics Society Beers Criteria ${ }^{\circledR}$. JAGS. 2019;67(4):6446. https://doi.org/10.1111/jgs.15766

23. Secoli SR, Marquesini EA, Fabretti SC, Corona LP, Romano-Lieber NS. Self-medication practice trend among the Brazilian elderly between 2006 and 2010: SABE Study. Rev Bras Epidemiol. 2018;21(Suppl 2):e180007. https://doi.org/10.1590/1980-549720180007.supl.2

24. Prado MAMB, Francisco PMSB, Barros MBA. Use of psychotropic medications in adults and elderly living in Campinas, São Paulo, Brazil: crosssectional population-based study. Epidemiol Serv Saúde. 2017; 26(4):747-58. https://doi.org/10.5123/s1679-49742017000400007

25. Prado MAMB, Francisco PMSB, Barros MBA. Diabetes in the elderly: drug use and the risk of drug interaction. Ciênc Saúde Colet. 2016;21(11):3447-58. https://doi.org/10.1590/1413-812320152111.24462015

26. Colet CF, Borges PEM, Amador TA. Profile of drug spend among elderly individuals from different socioeconomic groups. Rev Bras Geriatr Gerontol. 2016;19(4):591-601. https://doi.org/10.1590/1809-98232016019.150038

27. Restrepo SF, Vieira MRS, Barros CRS, Bousquat A. Medicines' private costs among elderly and the impairment of family income in a mediumsized municipality in the state of São Paulo. Rev Bras Epidemiol 2020;23:e200042. https://doi.org/10.1590/1980-549720200042

28. Ministério da Saúde (BR). Secretaria de Ciência, Tecnologia, Inovação e Insumos Estratégicos em Saúde. Departamento de Assistência Farmacêutica e Insumos Estratégicos. Relação Nacional de Medicamentos Essenciais: Rename 2020 [Internet]. Brasília: Ministério da Saúde, 2020[cited 2015 Oct 15]. Available from: http://bvsms.saude.gov.br/bvs/publicacoes/relacao_medicamentos_rename_2020.pdf

29. Polaro SHI, Montenegro LC. Fundamentals and practice of care in Gerontological Nursing. Rev Bras Enferm. 2017;70(4):671-2. https://doi. org/10.1590/0034-7167.2017700401 